\title{
Use of solid residue from the olive industry
}

\author{
By Ángeles Guinda \\ Instituto de la Grasa (C.S.I.C.), Avda. Padre García Tejero, 4, 41012-Sevilla, Spain. \\ E-mail: guinda@cica.es)
}

\section{RESUMEN}

\section{Uso de residuos sólidos a partir de la industria del olivo}

La investigación de nuevos aprovechamientos del olivar y en particular de lo subproductos del proceso de producción del aceite, tiene gran relevancia tanto en la economía como en el medio ambiente de los pueblos donde se desarrolla este cultivo. Son numerosos los trabajos publicados sobre la composición química de la aceituna y el aceite de oliva, en cambio sólo existen algunos estudios sobre el aislamiento e identificación de los compuestos de la hoja de olivo, en esta contribución se revisan los conocimientos sobre la composición química de la hoja de olivo, así como, las utilizaciones de los residuos sólidos -hoja de olivo y hueso de aceituna- que se originan en la producción del aceite de oliva y de aceitunas de mesa, como energía renovable y para la obtención de compuestos de alto valor añadido. Estos últimos, compuestos bioactivos dirigidos a los mercados de los aditivos alimentarios naturales, farmacéutico y cosmético, todos ellos muy receptivos en la actualidad a los productos de origen natural.

PALABRAS-CLAVE: Aprovechamiento de subproductos - Biomasa del olivar - Compuestos bioactivos - Hoja de olivo - Residuo sólido.

\section{SUMMARY}

\section{Use of solid residue from the olive industry}

Research into finding new uses for olive products, particularly by-products of olive oil production, is of great relevance not only to the economy, but also to the environment, in the towns where olives are grown. A large number of research articles has been published dealing with the chemical composition of olives and olive oil; however, only a few studies have centered on isolating and identifying compounds in the olive leaf. In this article an overview of the present body of knowledge on the chemical composition of the olive leaf will be presented. Also to be discussed is the use of solid residue, namely, the olive leaf and the olive stone. Both of these types of residue result from olive oil and table olive production, and can be used as a renewable energy source, as well as to obtain high added-value compounds. The latter, bioactive compounds are directed towards the cosmetic, pharmaceutical, and natural food supplements markets, all of which are currently highly receptive to products of natural origin

KEY-WORDS: Bioactive compounds - Olive biomass Olive leaf - Solid residue - Use of by-products.

\section{INTRODUCTION}

Olive tree cultivation in the Mediterranean goes back to ancient times, ever since the Roman Age
(Melillo, 1994), when olive cultivation spread throughout the entire Mediterranean basin. This longevous tree (Olea europaea, Oleaceae) integrates and identifies economically, socially, and culturally the inhabitants of this basin; olive oil constitutes the main source of nutritional fats and is a very valuable product for exportation. Today, Mediterranean countries account for around $98 \%$ of the world's olive cultivation (approximately ten million hectares); they produce about 1,9 million metric tonnes per annum of olive oil, in addition to 1,1 million $t$ of table olives (mean production during the four-season reference period from 1999/00 to 2002/03, http://www.internationaloliveoil.org/ ).

The use of solid residue, such as leaves and stones, is of great economic and social importance for the Mediterranean area, as these by-products accumulate in large amounts during olive oil production and the elaboration of table olives.

At present, it is possible to obtain activated carbon from olive stones (Rivera-Utrilla et al., 1986; Galiatsatou et al., 2001; Feng-Chin and Ru-Ling, 2000; Khalil et al., 2001; Blázquez et al., 2005), and the new biomass boiler system designs facilitate the use of olive stones as fuel for the generation of heat and electricity (Ortega-Jurado et al., 2004; Vlyssides et al., 2004). However, olive leaves, which are produced in large amounts, render scarce profits at present. Nevertheless, the market for natural ingredients and additives is rapidly growing, with such products obtaining high prices.

In the last few years, the possible toxicity of synthetic compounds (Fukushima and Tsuda, 1985; Fukushima et al., 1986; Stone, 2003), has increased interest in natural products and the food additives, cosmetics and pharmaceutical industries have improved their efforts in preparing bioactive compounds from natural products by extraction, fractionation, and purification.

\section{BIOACTIVE COMPOUNDS IN OLIVE LEAVES}

Olive leaves are agricultural residue resulting from the pruning of olive trees. The leaves may also be considered an easily available industrial byproduct, as they find their way to the olive mills in appreciable quantities. Olive leaves represent around $10 \%$ of the total weight of olives arriving to the mill (Espínola, 1996). Currently this by-product 
is not very profitable, given that in many countries the leaves have traditionally been used only as feed for livestock (Gómez-Cabrera et al., 1992; Sánchez et al., 2002; Ruíz et al., 2004). Often the leaves are disposed of by simply burning them together with the branches from pruning.

\subsection{Phenolic Components}

The leaves of Olea europaea L. have been studied, among other reasons, for their therapeutic effects. Interest in the potential health benefits of olive leaf extract dates back to the mid-nineteenth century, when reports were made of the ability of an extract (made from boiling the leaves) to reduce fever, including the ability to prevent or cure malaria symptoms even more effectively than quinine (Hanbury, 1854; Capretti and Bonaconza, 1949).

This singular physiological effect also encouraged identification of the principal agent involved. In the early $20^{\text {th }}$ century, the phenolic compound which is most abundant and characteristic in the fruit of the olive was isolated by Bourquelot and Vintilesco (1908). In 1960 Panizzi et al. established that the compound was a heterosidic ester of elenolic acid and hydroxytyrosol. Oleuropein is the principal member of the family of secoiridoids in the olive tree (Olea europaea L.). In 1974, Inouye et al. confirmed its structure by mass spectrometry.

For over thirty years since the isolation of oleuropein, extracts from various parts of the olive tree have been studied. The glucoside has been found in all of them: leaves, shoots, olive (pulp, husk and stone), wood, bark and roots (Pasquale et al., 1991; Juven, 1968). Le Tutour and Guedon (1992) point out that oleuropein content in olive leaves is very high, around $60-90 \mathrm{mg}$ per gram (dry material), although they also contain other compounds. Through hydrolysis, other phenolic compounds have been isolated and identified in olive leaves, although they are present in lesser quantity. These compounds include demethyloleuropein, ligstroside (Ragazzi et al., 1973), verbascoside (Fleuriet et al., 1984; SolerRivas et al., 2000) oleoside dimethylester (Panizzi et al. 1960), a non-glucosidic secoiridoid (Gariboldi et al., 1986), and oleuroside, an isomer of oleuropein (Kuwajima et al., 1988).

Additionally, olive leaves contain a significant amount of flavonoids. Found in the leaf are luteolin7-O-glucoside, luteolin-7-O-rutinoside, apigenin-7O-glucoside, rutin, luteolin, and apigenin, all of which have been identified by HPLC (De Laurentis, 1997; Ficarra and Ficarra 1991; Heimler et al., 2002). The purpose of this group of phenolic compounds present in the olive leaf seems to be, by virtue of their absorption spectrum, that of limiting the effects of UV light and the entailing oxidative damage (Galli and Visioli, 1999). Flavonoids also have the capacity to inhibit oxidation caused by free radicals (Bors et al., 1990 a and b).

The complexity of the chromatographic profiles of the fraction extracted with polar solvents from the olive leaf clearly indicates the presence of other phenolic derivatives, which may be present in the natural matrix. On the other hand, it can not be ruled out that the procedures of extraction and treatments of the sample may alter the structure of some of the secondary metabolites originally present in the plant tissue. Therefore, the need exists for the development of reliable methods for the analysis of the alcoholic extract of the leaf, prior to any stage of purification. De Nino et al. (1997) employ a method of direct analysis of the leaf extract, whose objective is the direct characterization of metabolites of the olive leaf using mass spectrometry (MS). This methodology would permit the "chemical characterization" of a particular variety, or the identification of compounds of great biological value.

Among the group of phenolic compounds present in the olive leaf, oleuropein and the products of its hydrolysis are those of the greatest biological interest (Fleming et al., 1973).

Oleuropein has a vasodilator effect, increases blood flow in the coronary arteries and improves arrhythmia (Zarzuelo et al., 1991; Manna et al., 2004). This compound has proven to be a potent antioxidant with anti-inflammatory properties (Visioli and Galli, 2002). In 1970 several articles presented the antiviral and antibacterial activity of calcium enolate (obtained by hydrolysis from oleuropein) (Elliot et al., 1975; Soret, 1969). Subsequent publications show that oleuropein also engages in antimicrobial activity against viruses, retroviruses, bacteria, yeasts, fungus, molds and other parasites (Juven et al., 1972; Tassou and Nychas, 1995; Aziz et al., 1998; Zanichelli et al., 2005). Other clinical effects of oleuropein are the fortification of cellular and organism protection through macrophage response (Visioli et al., 1998), the inhibition of plaque aggregation and eicosanoid production (Petroni et al., 1995), and a reduction by nearly $30 \%$ in the level of low density lipoproteins (LDL) (Visioli and Galli, 1994; Andrikopoulos et al., 2002).

\subsection{Terpenic components}

Vázquez-Roncero and Janer (1969) contributed diverse qualitative results of the presence of terpenic acids in the olive leaf. Later, Mussini et al. (1975) isolated alpha-amyrine and confirmed the presence of maslinic acid. Bianchi et al. $(1993,1994)$ analyzed these compounds and some of those found by Vázquez-Roncero and collaborators, in three Italian varieties.

Among the terpenic compounds in the olive leaf, one to take notice of is oleanolic acid (3-betahydroxy-28-carboxyolean). This compound is found extensively throughout the plant kingdom, and in the olive leaf it occurs in free acid form in considerable proportions, accounting for $\cong 3 \%$ of dry leaf weight (Albi et al., 2001). Oleanolic acid is biologically active with antiabortive, anti-cariogenic, anti-fertility, antihepatotoxic, anti-inflammatory, antisarcomic, cancerpreventive, cardiotonic, diuretic, hepatoprotective and uterotonic properties. Numerous studies have been published on the possible biological activity of 
this acid and its glucosides. It has been studied in its activity as an inhibitor of the proliferation of leucemic cells (Es-Saady et al., 1994), as a hypoglucemiant (Yoshikawa et al., 1994), as an anti-tumoral agent (Gerhauser et al., 2003), as a hepatoprotective agent (Yim et al., 2001), as an anti-inflammatory (Ismaili et al., 2002; Takeoka et al., 2000 and Choi et al., 2002), as an anti-bacterial (Sasazuka et al., 1995), as an inhibitor of the production of nitric acid (Honda et al., 1997), as an anti-HIV agent (Mengoni et al., 2002), in its anti-atherogenic activity (Somova et al., 2003) and as a cardiotonic (Somova et al., 2004). Also in existence are publications and patents for the preparation of functional foods with oleanolic acid (Hassel et al., 1998; Putte, 2000; Guinda et al., 2004).

\subsection{Liposoluble compounds}

In 1973, Janer isolated by Thin Layer Chromatography some liposoluble compounds present in olive leaf extract (hexane extract) and analyzed the fatty acids of the triacylglycerols from leaves. In recent years, Guinda et al. (2002) have isolated, identified and quantified numerous components of a hexane extract of olive leaves, consisting of: saturated hydrocarbons, squalene, ester waxes, alpha-tocopherol, triglycerides, betacarotene, linear alcohols, alpha- and beta-amyrine, and beta-sytosterol. These compounds have been found in five Spanish varieties (Picual, Hojiblanca, Empeltre, Arbequina and Cornicabra). The concentration (ppm) of the compounds ranged from the following: 050-3400 (saturated hydrocarbons), 38-152 (squalene), 915-1874, 28-100 (betacarotene), 832-1396 (triglycerides), 41-125 (alphatocopherol), 714-2500 (beta- sytosterol), 95-311 (alcohols) and 342-837 (terpenic dialcohols). The most numerous hydrocarbons in all of the varieties studied are C29, C31 and C33. The waxes are mainly constituted of fatty acids and the terpenic alcohols of the olive leaf (palmitic, oleic, and linoleic; alpha- and beta-amyrine). The terpenic dialcohols found in the olive leaf are uvaol and erythrodiol, with the uvaol content always higher than that of erythrodiol, which is the opposite case in olive oil. A large part of the compounds analyzed in the hexane extract of the olive leaf, such as alpha-tocopherol, beta-carotene, alpha- and beta-amyrine, squalene and beta-sytosterol, are bioactive compounds capable of modulating human physiological systems. Therefore, these compounds have multiple applications in the pharmaceutical, cosmetics and food additives industries. Numerous articles have been published on the antioxidant activity of alphatocopherol, as well as on the protective effects of alpha-tocopherol and of beta-carotene with regard to atherogenesis (Devaraj et al., 1998) and cancer (Virtamo et al., 2000; 2003). Other publications examine the potential use of squalene (Kelly, 1999) and its preventive effect on colon cancer (Newmark, 1999; Rao et al., 1998). Still others examine the potential health benefits of the phytosterols: betasytosterol reduces cholesterol levels in the blood, as well as being effective at in vitro reduction of breast cancer cells (Awad et al., 2001; 2003). Another area of study has been the anti-inflammatory activity of the triterpenic dialcohols of the olive leaf (alpha- and beta-amyrine) (Martín-Cordero et al., 2001; Puerta et al., 1997).

\subsection{Other compounds}

The olive tree, like other members of the family of Oleaceas, is distinguished by it capacity for the biosynthesis of mannitol and oligosaccharides of the rafinose family (raffinose and, above all, stachyose), as well as sucrose, as direct products of photosynthesis (Flora and Madore, 1993; Stoop et al., 1996). Mannitol, a hexitol derivative of mannose, offers a series of properties with advantageous applications in the food and pharmaceutical industries. Its sweetening potency is equivalent to $70 \%$ that of sucrose; it has a low caloric value (2 $\mathrm{kcal} / \mathrm{g}$ ), it does not cause caries and its metabolism in humans is not dependent on insulin, which makes it suitable for consumption by diabetics. Additionally, it has healthful effects as an antioxidant (Wisselink et al., 2002) and is of therapeutic use in severe head injuries, as it is effective in the reduction of intracraneal pressure (Brain Trauma Foundation, 1996; Filipo et al., 1997; Unterberg et al., 1997). Its industrial preparation is achieved by means of catalytic hydrogenation of sugars. As this chemical process yields a scant quantity of mannitol, in recent years research has been conducted into alternative biotechnological processes. The use of olive leaves as raw material in obtaining mannitol offers a promising alternative, as they contain between 10 and $20 \mathrm{mg}$ per gram of plant tissue of this carbohydrate (Flora and Madore, 1993; Sánchez, 1998).

Recently, Campeol et al., 2004, have isolated and identified through mass spectrometry (EIMS) and nuclear magnetic resonance ( $\mathrm{H}$ and $\mathrm{C} R M N)$, a new compound: 1.5-Anhydroxylitol. This compound, never before detected in the plant kingdom, was obtained in the range of 0.1 to $1 \%$.

For the purpose of obtaining basic data for the processing and manufacture of foods, Ok-Hwan et al. (2005) have analyzed the contents of the leaf as to moisture, ash, crude protein, fat, carbohydrates, the principal amino acids (glutamic and aspartic) and principal free sugar (sucrose), as well as the concentration of $\mathrm{Ca}$ and vitamins $\mathrm{A}$ and $\mathrm{C}$. Neither vitamins $\mathrm{B} 6$ nor $\mathrm{B} 12$ were detected.

\section{USES OF OLIVE LEAVES}

\subsection{The Benefits of extracts}

At present, there is a growing body of evidence for the beneficial role that the phytonutrients play in relation with the prevention of serious diseases (Arai, 1997; Ovesen, 1997). The enormous interest in these substances in recent years as additives or 
natural food ingredients has gone beyond food preparation and conservation, into the new area known as nutraceutics. This science studies the therapeutic effects of the components of foods. It is known that "functional foods" can modulate human physiological systems, such as the immunological, endocrinal, nervous, circulatory and digestive systems, with this last a proven object of study (Hassel, 1998). At present, several natural extracts, among them that of the olive leaf, are used in the manufacture of functional foods (Micol et al., 2003).

Diverse epidemiological studies have proven the association between diets rich in antioxidant compounds and a reduction in the risk of contracting certain types of cancer, cardiovascular and ocular diseases in which oxidative stress plays an important part in their development (Garewall, 1997; Visioli et al., 2000). As a result, nutritional recommendations generally include the consumption of food and drink rich in antioxidant compounds (Packer et al., 1999). It is also becoming more frequent to design foods with antioxidant functions (Hollingsworth, 1998). Among the antioxidants present in the olive leaf, the phenolic compounds are notable. Phenolic compounds are one of the main products of the secondary metabolism and comprise a wide range of structural classes and biological functions.

Olive leaf extracts are well-known for their antioxidant properties (Susnik-Rybarski, et al., 1983; Benavente-García et al., 2000; Briante et al., 2001; De la Fuente et al., 2005; Bouaziz and Sayadi, 2005; Coll et al., 2000). Other significant qualities associated with olive leaf extracts include that of being a hypotensor (Khayyal et al., 2002), a hypoglucemiant (Manceau et al., 1942; González et al.,1992; Trovato et al., 1993; Komaki et al., 2003), a hypocholesterolmiant (De Pasquale et al., 1991), cardioprotective (Cicosta et al., 1990), radioprotective (Benavente-García et al., 2002), anti-HIV (Lee-Huang et al., 2003) and anti-viral (Micol et al., 2003), antimutagenic (Yahiaoui et al., 1994), anticarcinogenic (Pieroni et al., 1996; Onderoglu et al., 1999; Hamdi and Castellon. 2005; Kosak and Stern, 1962), hypotensive (Kosak and Stern, 1960), and anti-inflammatory (Fehri et al., 1996). Of special interest is the extract's antimicrobial activity, in the possibility of utilizing them as alternative food additives (Markin et al., 2003; Tassou and Nychas, 1994). Similarly, various authors have reported on the antibacterial activity of the phenolic compounds of the olive tree (Tassou and Nychas, 1995; Tranter, 1993; Rodríguez et al., 1988; Paster et al., 1988; Nychas et al., 1990). Other studies include one conducted on the effect of an aqueous extract of olive leaf on the thyroid gland in laboratory animals (Al-Qarawi et al., 2002), and another on the antioxidant activity of an olive leaf extract against sunflower oil oxidation (Farag et al., 2002).

In the olive tree, phenolic compounds are more abundant in the fruit than in the leaf; even so, they are present in significant amounts (Le Tutour and Guedon, 1992; Paiva-Martins and Gordon, 2001), which makes utilization of the leaves worthwhile. In addition, the leaf contains a considerable amount of terpenic compounds, whose biological activity is well-known. A specific review of the pharmacological activity of oleanolic acid has been published (Tian et al., 2002), as well as a study of the anticarcinogenic effect of ursolic acid (Es-Saady et al., 1994, 1996a y 1996b). Basically, the leaf represents a by-product whose potential for use is still under development. Its use would facilitate the obtaining of natural products at a competitive cost.

\subsection{Uses of the extracts}

Up to now, use of the olive leaf has been made principally through formulations which include an extract of the same, without any previous separation of the active compounds. There are numerous preparations of this type on the market; they are used as complements to the treatment of certain diseases or as nutritional supplements. New patents appear daily for functional foods or cosmetics based on olive leaf extracts. The patents are quite varied in their formulation; for example, there are liquid preparations with alcohol and with glycerin (Oliveda Network SL, 2005 a y b). Equally diverse are the applications to which these formulations are destined: manufacture of dietetic bread for diabetics (Scheneder, 1985); preparations which contain lycopene and olive leaf extract for use in food or cosmetics (Coll et al., 1999); use of olive leaf extracts in dietetic cookies (Shtukatur, 2003); the manufacture of a nutritional supplement with physiological effects containing olive leaf extract (Stueckler 1998); an extract of olive leaves to combat free radicals, and their use in dietetic foods and in cosmetics (Amari 1998).

\section{OBTAINING HIGH ADDED-VALUE COMPOUNDS FROM THE OLIVE LEAF}

Works on obtaining bioactive compounds from the olive leaf are recent and not very numerous. The techniques employed range from biotransformation (Ryan et al., 2002; Verhe et al., 1992; Briante et al., 2001), solid/liquid extraction and subsequent fractionation of the extract (Albi et al., 2001), and supercritical fluid extraction (SFE) (Lucas et al., 2002; Tabera et al., 2004b).

Briante et al., (2001, 2002 and 2004) have proposed a bioreactor for obtaining large quantities of hydroxytyrosol of high purity (91-94\% in weight), starting from olive leaf extract. The process consists of extraction with ethanol/water (1:1) from the leaf and subsequent biotransformation of the extract, by means of a hyperthermophilic beta-glucosidase, partially purified and immobilized in a support of chitosan (polysaccharide obtained from the shells of crustaceans). The bioreactor is separated into two chambers; the first column is filled with the matrix of the chitosan enzyme and is used for the hydrolysis of oleuropein into aglucone. The second column of the bioreactor is used as a second reaction chamber at high temperature and under $\mathrm{pH}$-controlled 
conditions, permitting total hydrolysis of the aglucone of oleuropein into hydroxytyrosol. Lucas et al., (2002), obtain concentrates of alpha-tocopherol directly from the leaves, by means of supercritical fluid extraction (SFE). Tabera et al., (2004b), have patented a process for obtaining high added-value compounds from the olive leaf, consisting mainly of a first stage of solid/liquid extraction with solvents of decreasing polarity, and subsequent fine fractionation of the different extracts through extraction with supercritical $\mathrm{CO} 2$, in countercurrent (CC-SFE). With this method they have obtained concentrates of alpha-tocopherol (Tabera et al., 2004a) and hydroxytyrosol, among others. Guinda and colaborators, have developed a procedure for obtaining terpenic acids from the leaves of Olea europaea by means of extraction from the leaf with an organic polar solvent, and separation of this acid by crystallization. This patented process (Guinda et al., 2000) allows for obtaining oleanolic acid with approximately $93 \%$ purity. Subsequent purification by means of a simple thermal treatment allows for this acid to be obtained with a purity of $98-99 \%$. The advantage of this procedure is even greater when taking into account that even though this triterpenic acid is found extensively throughout the plant kingdom, in the olive leaf, oleanolic acid occurs in

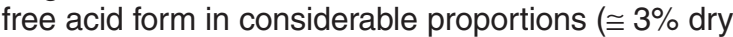
leaf weight). Additionally, there is a considerable amount of leaves available annually, when including those coming from pruning and those separated from the olives in the mills.

At the present time, is being investigated in the Instituto de la Grasa (CSIC), (Spanish project AGL 2003-02795), a new and encouraging process that involves a continuous separation procedure, by means of molecular distillation (Short Path Distillation), of the natural compounds present in alcoholic olive leaf extract.

\section{FINAL CONSIDERATIONS}

To increase the economic performance of the olive and related industries, it is of great importance to make use of a by-product like the olive leaf. Bioactive compounds obtained from the leaves have dietetic, pharmaceutical and cosmetic applications. Using this residue not only meets with the requirement of its effective and innocuous elimination: as well as preventing environmental problems, it also creates new sources of wealth which contribute to higher profitability in the initial industrial process. Moreover, it should be taken into account that making the management of residue profitable generates all sorts of new industries, with the resulting social gains.

\section{ACKNOWLEDGEMENTS}

This work was supported by the MCYT (AGL 2000-1531-C02 y AGL 2003-02795).

\section{REFERENCES}

Albi, T., Guinda, A., Lanzón A. (2001). Procedimiento de Obtención y Determinación de Ácidos Terpénicos de la Hoja del Olivo (Olea Europaea). Grasas y Aceites, 52, 275-278.

Al-Qarawi, AA., Al-Damegh, MA., ElMougy, SA. (2002). Effect of freeze dried extract of Olea europaea on the pituitary-thyroid axis in rats. Phytother Res., 16(3), 286-7.

Amari, G. (1998). Use of an extract from the leaves of Olea europea as an antiradical Patent $\mathrm{N}^{\circ} \mathrm{EP}$ 0937455-A1 (19.02.1998).

Andrikopoulos, NK., Antonopoulou, S., Kaliora, AC. (2002). Oleuropein inhibits LDL oxidation induced by cooking oil frying by-products and platelet aggregation induced by platelet-activating factor. Lebensmittel-Wissenschaft Technol., 35 (6), 479-484.

Arai, S. (1997). Functional foods Nippon Yakurigaku Zasshi, 110, 7-10.

Awad, AB., Roy, R., Fink, CS. (2003). Beta sytosterol, a plant sterol, induces apoptosis and activates key caspases in MDA-MB-231 human breast cancer cells. Oncol-Rep., 10, 497-500.

Awad, AB., Willians, H., Fink, CS. (2001). Phytosterols reduce in vitro metastatic ability of MDA-MB-231 human breast cancer cells. Nutr-Cancer, 40, 157-164.

Aziz, NH., Farag, SE., Mousa, LA., Abo-Zaid, MA. (1998). Comparative antibacterial and antifungal effects of some phenolic compounds. Microbio,. 93, 43-54.

Benavente-García, O., Castillo, J., Lorente, J., Alcaráz, M. (2002). Radioprotective effects in vivo of phenolics extracted from Olea europaea L. leaves against X-rayinduced chromosomal damage: comparative study versus several flavonoids and sulfur-containing compounds. J. Med. Food., 5(3), 125-35.

Benavente-García, O., Castillo, J., Lorente, J., Ortuño, A., Del Rio, JA. (2000). Antioxidant activity of phenolics extracted from Olea europaea L. leaves. Food Chem., 68 (4), 457-462.

Bianchi, G., Pozzi, N., Vlahov, G., (1994). Pentacyclic triterpene acids in olives. Phytochemistry, 37, 205-207.

Bianchi, G., Vlahov, G., Anglani, C., Murelli, C., (1993). Epicuticular wax of olive leaves. Phytochemistry, 32, 49-52.

Blázquez, G., Hernainz, F., Calero, M., Ruiz-Nunez, LF. (2005). Removal of cadmium ions with olive stones: the effect of some parameters Process Biochemistry, 40 (8), 2649-2654.

Bors, W., Hellers, W., Michel, C., Saran, M. (1990a). Radical chemistry of flavonoid antioxidants. In, Antioxidants in therapy and preventive medicine. Vol. 1, pp. 165-170. New York: Plenum Press.

Bors, W., Hellers, W., Michel, C., Saran, M. (1990b). Flavonoids as antioxidants: determination of radicalscavenging efficiencies. In: L. Packer \& A. N. Glazer, Methods in enzymology. Vol. 186, pp. 343-355. San Diego, CA: Academic Press.

Bouaziz, M., Sayadi, S. (2005) Isolation and evaluation of antioxidants from leaves of a Tunisian cultivar olive tree. Eur. J. Lipid Sci. Technol., 107 497-504.

Bourquelot, E., Vintilesco, J. (1908). Sur l'oleuropein, nouveau principe de nature glucosidique retiré de l'olivier (Olea europaea L.). Compt. Rend. Hebd. Acad. Sci. Pari,s 147, 533-535.

Brain Trauma Foundation. (1996). The use of mannitol in severe head injury. J. Neurotrauma, .13, 705-709.

Briante R, Patumi M, Febbraio F, Nucci R. 2004. Production of highly purified hydroxytyrosol from Olea europaea 
leaf extract biotransformed by hyperthermophilic betaglycosidase. J Biotechnol 111 (1), 67-77.

Briante, R., Batumi, M., Terenziani, S., Bismuto, E., Febbraio, F., Nucci, R. (2002b). Olea europaea L. leaf extract and derivatives: antioxidant properties. J Agric Food Chem., 50 (17). 4934-4940.

Briante, R., La Cara, F., Febbraio, F., Batumi, M., Nucci, R. (2002a). Bioactive derivatives of oleuropein by a biotransformation on Olea europaea leaf extracts. $J$. Biotechnol., 93, 109-119.

Briante, R., La Cara, F., Tonziello, MP., Febbraio, F. Nucci, R. (2001). Antioxidant activity of the main bioactive derivatives from oleuropein hydrolysis by hyperthermophilic -glycosidase. J. Agric. Food Chem., 49 (7), 3198-3203.

Campeol, E., Flamini, G., Cioni, PL., Morelli, I., D’Andrea, F., Cremonini, R. (2004) 1,5-Anhydroxylitol from leaves of Olea europaea. Carbohydrate Res., 339, 2731-2732.

Capretti, G., Bonaconza, E. (1949). Effects of infusions or decoctions of olive leaves (Olea europaea) on some physical constants of blood and components of metabolism. Giorn.Clin.Med., 30, 630-642.

Cicosta, C., Occhiuto, F., Gregorio, A., Toigo, S., Pasquale, A. (1990). Cardiovascular activity of the young shoots and leaves of Olea europaea $L$. and of oleuropein. Plant Med. Phytother., 24(4), 264-277.

Coll, D., Mathonnet, JP., Zannini, G. (1999). Dietetic and/or cosmetic preparation comprising a mixture of lycopene and olive leaf extract. Patent $\mathrm{N}^{\circ}$ FR 2792831-A1 (28.04.1999).

Coll, D., Mathonnet, JP., Zannini, G. Benavente-García, O., Castillo, J., Lorente J. (2000). Antioxidant activity of phenolics extracted from Olea europaea L. leaves. Food Chem., 68 (4), 457-462.

Choi, J., Lee, KT., Jung, H., Park, HS., Park, HJ. (2002) Anti-rheumatoid arthritis effect of the Kochia scoparia fruits and activity comparison of momordin Ic, its prosapogenin and sapogenin. Arch. Pharm. Res., 25(3), 336-42

De la Fuente, P., Chamarro, P., Moreno, M., Poza, MA. (2005). Antioxidant properties of Olixxol(R) (hydroxytyrosol) from olive leaves (Olea europaea L.). Innovations Food Technol., 26, 76-79.

De Laurentis, N., Crescenzo, G., Lai, OR., Milillo, MA. (1997) Investigation on the extraction and concentration of oleuropeina and flavonoids in Olea europaea L. based products. Pharm Pharmacol Lett., 7 , 27-30.

De Lucas, A., Martínez de la Ossa, E., Rincón, J., Blanco, MA., Gracia, I. (2002) Supercritical fluid extraction of tocopherol concentrates from olive oil tree leaves. J. Supercrit. Fluids, 22, 221-228.

De Nino, A., Lombardo, N., Perri, E., Procopio, A., Raffaelli, A., Sindona, G. (1997) Direct Identfication of Phenolic Glucosides from Olive Leaf Extracts by Atmospheric Pressure Ionization Tandem Mass Spectrometry. J. Mass Spectrometry, 32, 533-541.

De Pasquale, R., Monforte, M.T., Trozzi, A., Raccuia, A., Tommasini, S. (1991). Effects of leaves and shoots of Olea europaea and oleuropein on experimental hypercholesterolaemia in the rat. Plant Med. Phytother., 25(2/3), 134-140.

Devaraj, S., Jialal, I. (1998). The effects of alphatocopherol on critical cells in atherogenesis. CurrOpin-Lipidol., 9, 11-15.

Elliot, G., Buthala, D., DeYoung, F. (1975). Preliminary safety studies with calcium elenolate, an antiviral agent. Antimicrob. Agents and Chemother., 8, 173-199.
Espínola, F. (1997) Cambios tecnológicos en la extracción del aceite de oliva virgen. Alimentación, Equipos y Tecnología, 21(5), 314-389.

Es-Saady, D., Najid, A., Simon, A., Denizot, Y., Chulia, A. J.,Delage, C. (1994). Effect of ursolic acid and its analogues on soybean 15-lipoxygenase activity and the proliferation rate of a human gastric tumor cell line. Mediators Inflammation, 3, 181-184.

Es-Saady, D., Simon, A., Jayat-Vignoles, C., Chulia, A. J., Delage, C. (1996a). MCF-7 cell cycle arrested at G1 through ursolic acid, and increased reduction of tetrazolium salts. Anticancer Research, 16, 481-486.

Es-Saady, D., Simon, A., Ollier, M., Maurizis, J. C., Chulia, A. J., Delage, C. (1996b). Inhibitory effect of ursolic acid on B16 proliferation through cell cycle arrest. Cancer Letters, 106, 193-197.

Farag, RS., Abd-Elmoien, NM., Mahmoud, EA. (2002). Antioxidant properties of olive phenolic compounds on sunflower oil stability. Advances Food Sci., 24 (3), 99-105.

Fehri, B., Aiache, JM., Mrad, S., Korbi, S., Lamaison, JL. (1996). Olea europaea L. : stimulant, anti-ulcer and anti-inflammatory effects. Boll. Chim. Pharm., 135(1), 42-49.

Feng-Chin, W., Ru-Ling, T. (2000). Adsorption characteristics and pore structure of activated carbons prepared from agricultural wastes Taiwanese J. Agric Chem. Food Sci., 38 (3), 205-213.

Ficarra, P., Ficarra, R. (1991). HPLC analysis of oleuropein and some flavonoids in leaf and bud of Olea europaea L. II Farmaco 46 (6), 803-815.

Fleming, HP., Walter, WM., Etchells, JL. (1973). Antimicrobial properties of oleuropein and products of its hydrolysis. Appl Microbiol., 26 (5), 777-782.

Fleuriet, A., Macheix, JJ., Andary, C.; Villemur, P. (1984). Mise en évidence et dosage par chromatographie liquide à haute performance du verbascoside dans le fruit de six cultivars d'Olea europaea L. C.R. Acad. Sci. Paris, Ser. III. 7, 253-256.

Flora, LL., Madore, MA. (1993) Stachyose and mannitol transport in olive (Olea europaea L.). Planta, 189, 484-490.

Fukushima, NS. Tsuda, H. (1985). Carcinogenity and modification of the carcinogenic response by $\mathrm{BHA}$, BHT and other antioxidants. Crit. Rev. Toxicol., 15, 109-150.

Fukushima, NS., Tamano, S., Hiroe, M., Hagiwara, A (1986). Dose response in Butylated Hydroxyanisole. Induction of forestomach carcinogenesis in F 344 rats. J. Natl. Cancer Inst., 77, 1261-1265.

Galiatsatou, P., Metaxas, M., Kasselouri-Rigopoulou, V. (2001). Mesoporous activated carbon from agricultural byproducts. Mikrochimica Acta, 136 (3/4), 147-152.

Galli, C.; Visioli, F. (1999). Antioxidant and other activities of phenolics in olives/olive oil, typical components of the Mediterranean diet. Lipids, 34, 523-526.

Garewall, HG., (1997). In: Antioxidants and disease prevention. CRC Press. Boca Raton. USA.

Gariboldi, P, Jommi, G., Verotta, L. (1986). Secoiridoids from Olea europaea. Phytochemistry, 25 (4), 865-869.

Gerhauser, C., Klimo, K., Heiss, E., Neumann, I., GamalEldeen, A., Knauft, J., Liu, GY., Sitthimonchai, S., Frank, N. (2003) Mechanism-based in vitro screening of potential cancer chemopreventive agents. MutatRes., 523-524, 163-72.

Gómez-Cabrera, A., Garrido, A., Guerrero, JE., Ortiz, V. (1992). Nutritive value of the olive leaf: effects of 
cultivar, season of harvesting and system of drying. $J$. Agric. Sci., Cambridge, 119, 205-210.

González, M, Zarzuelo A, Gamez MJ, Utrilla MP, Jiminez $\mathrm{J}$ and Osuna I. (1992). Hypoglycaemic activity of olive leaf. Planta Medica. 58(6), 513-515.

Guinda A, Albi T, Perez-Camino MC., Lanzón, A. (2004). Supplementation of oils with oleanolic acid from the olive leaf (Olea europaea). European J. Lipid Sci. Technol., 106 (1), 22-26.

Guinda, A., Albi, T., Lanzón, A. (2000) Procedimiento para la obtención de ácidos terpénicos a partir de la hoja de Olea europaea. Patent $N^{\circ}$ ES 2160553-A1 (19.04.2000).

Guinda, A., Lanzón, A., Ríos, JJ., Albi, T. (2002) Aislamiento y cuantificación de los componentes hoja del olivo: Extracto de hexano. Grasas y Aceites, 53, 240-245.

Hamdi, HK., Castellon, R. (2005). Oleuropein, a non-toxic olive iridoid, is an anti-tumor agent and cytoskeleton disruptor. Biochem. Biophys. Res. Comm,. 334, 769778.

Hanbury, D. (1854). On the febrifuge properties of the olive (Olea Europaea, L). Pharmaceutical J. Provincial Transactions. 353-354.

Hassel, CA. (1998). Animal models: new cholesterol raising and lowering nutrients. Curr. Opin. Lipidol,. 9, 7-10.

Heimler, D., Cimato, A., Sani, G., Pieroni, A., Galardi, C., Romani, A. (2002). Flavonoids from olive leaves (Olea europaea L.) as affected by light. J. Commodity Sci., 41 (1), 31-39.

Hollingsworth, P., (1998). We all scream for...green tea?. Food Technol, . 52, 28-31.

Honda, T., Finlay, HJ., Gribble, GW., Suh, N., Sporn, MB. (1997). New enone derivatives of oleanolic acid and ursolic acid as inhibitors of nitric oxide production in mouse macrophages. Bioorg. Med. Chem. Lett., 7(13), 1623-1628

Inouye, H., Yoshida, T., Tobita, S., Tanaka, K., Nishioka, T. (1974). The monoterpene glucosides and related natural compounds. The absolute structure of oleuropein, kingiside and morroniside. Tetrahedron, 30, 201-209.

Ismaili, H., Sosa, S., Brkic, D., Fkih-Tetouani, S., Ilidrissi, A., Touati, D., Aquino, RP., Tubaro, A. (2002). Topical anti-inflammatory activity of extracts and compounds from Thymus broussonettii. J.Pharm.Pharmacol., 54(8), 1137-40.

Janer, ML. (1973) Componentes liposolubles de las hojas de olivo. Tesis Doctoral. Universidad de Sevilla. España.

Juven, B., Henys, Y. (1972). Studies on the mechanism of the antimicrobial action of oleuropein. .J Applied Bacteriol,. 35, 559-567.

Juven, B., Samish, Z., Henis, Y. (1968). Identification of oleuropein as a natural inhibitor of lactic acid fermentation. Israel J. Agric. Res., 18, 137-138.

Kelly, GS. (1999). Squalene and its potential clinical uses. Altern.Med.Rev. 4, 29-36.

Khalil, LB., Girgis, BS., Tawfik, T. (2001). Decomposition of $\mathrm{H} 2 \mathrm{O} 2$ on activated carbon obtained from olive stones. J.Chem.. Technol. Biotechnol., 76, 1132-1140.

Khayyal, MT., El-Ghazaly, MA., Abdallah, DM., Nassar NN., Okpanyi, SN., Kreuter, MH. (2002). Blood pressure lowering effect of an olive leaf extract (Olea europaea) in L-NAME induced hypertension in rats. Arzneimittel Forschung, 52(11), 797-802.

Komaki, E., Yamaguchi, S., Maru, I., Kinoshita, M., Kakehi, K., Ohta, Y., Tsukada, Y. (2003). Identification of anti-alpha-amylase components from olive leaf extracts. Food Sci. Technol. Res., 9 (1), 35-39.

Kosak, R., Stern, P. (1960). On the mechanism of action of the hypotensive principle of olive leaves. Naunyn SchmiedebergsArch.Exp.Pathol. Pharmakol., 238, 117-9

Kosak, R., Stern, P. (1962). Effect of an extract of olive leaves on copper metabolism in the rat. Arzneimittelforschung., 12, 919-921.

Kuwajima, H., Uemura, T., Takaishi, K., Inoue, K., Intuye, H. (1988). A secoiridoid glucoside from Olea europaea. Phytochemistry, 27 (6), 1757-1759

Le Tutour, B., Guedon, D. (1992). Antioxidative activities of Olea europaea leaves and related phenolic compounds. Phytochemistry., 31, 1173-1178.

Lee-Huang S, Zhang L, Huang PL, Chang YT, Huang PL. (2003). Anti-HIV activity of olive leaf extract (OLE) and modulation of host cell gene expression by HIV-1 infection and OLE treatment. Biochem Biophys Res Communications, 307(4), 1029-1037.

Manceau, P., Netien, G., Jardon, P. (1942). Hypoglycaemic action of extracts of olive leaves. Comptes rendues de la Sociéte Biologique. 136, 810-811.

Manna, C., Migliardi, V., Golino, P., Scognamiglio, A., Galletti, P., Chiariello, M., Zappia, V. (2004). Oleuropein prevents oxidative myocardial injury induced by ischemia and reperfusion. J. Nutritional Biochem, 15 (8), 461-466.

Markin, D., Duek, L., Berdicevsky, I. (2003). In vitro antimicrobial activity of olive leaves. Mycoses. 46(34), $132-6$.

Martín-Cordero, C., Reyes, M., Ayuso, MJ., Toro, MV. (2001). Cytoxic triterpenoids from Erica andevalensis. Z-Naturforsch., 56, 45-48.

Melillo, L. (1994). Diuretic plants in the paintings of Pompeii degli Studi di Napoli, Italy. Am. J. Nephrol., 14(4-6), 423-425.

Mengoni, F., Lichtner, M., Battinelli, L., Marzi, M., Mastroianni, CM., Vullo, V., Mazzanti, G. (2002). In vitro anti-HIV activity of oleanolic acid on infected human mononuclear cells. Planta-Med., 68(2), 111-114.

Micol, V., Estepa, A., Catarla, N., Pérez-Fons, L., Saura, D., Ferrer-Montiel, A., Cartagena, V. (2003). New applications of herbal extracts for functional food and pharmaceuticals. Part 2. Agro Food Industry hi-tech., 14 (6), 14-16.

Mussini, P., Orsini, F., Pelizzoni, F. (1975). Triterpenes in Leaves of Olea Europaea. Phytochemistry, 14, 11351139.

Newmark, HL. (1999). Squalene, olive oil, and cancer risk. Review and hypothesis. Ann.N.Y.Acad. Sci., 889, 193-203.

Nychas, GJE., Tassou, SC., Board, RG. (1990) Phenolic extract from olives: inhibition of Stapylococcus aureus. Lett. Appl. Microbiol., 10, 217-220.

Ok-Hwan, L., Hee-Bong, L., Junsoo, L., Jong-Youn, S., Seong-Kap, R., Hyun-Duk, K., Young-Chan, K., BooYong, L. (2005). Chemical properties of olive and bay leaves. J. Korean Soc. Food Sci. Nutrition, 34 (4), 503508.

Oliveda Network SL. (2005a). Preparation based on liquid olive leaf extract. Patent $\mathrm{N}^{\circ}$ DE 202005006446-U1 (21.04.2005).

Oliveda Network SL. (2005b). Preparation based on liquid olive leaf extract and glycerol. Patent $\mathrm{N}^{\circ} \mathrm{DE}$ 202005007222-U1 (06.05.2005).

Onderoglu, S., Soze, r S., Erbil, KM., Ortac, R., Lermioglu, F. (1999). The evaluation of long-term effects of cinnamon bark and olive leaf on toxicity induced by 
streptozotocin administration to rats. J Pharm Pharmacol., 51(11), 1305-12.

Ortega-Jurado, A., Palomar-Carnicero, JM., CruzPeragon, F. (2004) Integral olive kernel elaboration with electricity generation compared with actual system of obtaining olive virgin oil. Grasas y Aceites , 55 (3), 303-311.

Ovesen, L. (1997) Regulatory aspects of functional foods. Eur. J. Cancer Prev., 6, 480-482.

Packer, L., Hiramatsu, M.,Yoshikawa, T. (1999). Antioxidant Food Supplements. In: Human Health Academic Press. London.

Paiva-Martins, F., Gordon, MH. (2001). Isolation and characterization of the antioxidant component 3,4dihydroxyphenylethyl 4-formyl-3-formylmethyl-4hexenoate from olive (Olea europaea) leaves. J Agric Food Chem., 49(9), 4214-4219.

Panizzi, L., Scarpati, ML., and Oriente, G., (1960). The constitution of oleuropein, a bitter glucoside of the olive with hypotensive action. Gazzetta Chimica Italiana 90, 1449-1485.

Pasquale, AD., Monforte, MT., Calabro, ML., (1991). HPLC analysis of oleuropein and some flavonoids in leaf and bud of Olea Europaea L. I/ Farmaco, 46 (6), 803-815

Paster, N., Juven, BJ., Harshemesh, H. (1988). Antimicrobial activity and inhibition of aflatoxin B1 formation by olive plant tissue constituents. J. Appl. Bacteriol., 64, 293-297.

Petroni, A., Blasevich, M., Salami, M., Papini, N., Montedoro, GF., Galli, C. (1995). Inhibition of platelet agregation and eicosanoid production by phenolic components of olive oil. Thrombosis Research., 78, 151-160.

Pieroni, A., Heimler, D., Pieters, L., van Piel, B., Vlietinck, AJ. (1996). In vitro anti-complementary activity of flavonoids from olive (Olea europaea L.) leaves. Pharmazie, 51(10), 765-768.

Puerta, R., Maestro-Durán, R., and Ruiz-Gutiérrez, V. (1997). Actividad farmacológica de la fracción de esteroles y alcoholes triterpénicos aislada del aceite de olive virgen. Grasas y Aceites, 48 93-95.

Putte, V., Karel-Petrus, AM. (2000). Process for preparing food products fortified with oleanolic acid. Patent. EP 1013752-A1. (Unilever N.V.; Unilever PLC, Neth.)

Ragazzi, E., Veronese, G., Guiotto, A. (1973). Demethyloleoeuropein, a new glucoside isolated from ripe olives. Ann . Chim., 63, 13-20.

Rao, CV., Newmark, HL., Reddy, BS. (1998). Chemopreventive effect of squalene on colon cancer Carcinogenesis, 19, 287-290.

Rivera-Utrilla, J., Ferro-García, MA., Mingorance, MD., Bautista-Toledo, I. (1986). Adsorption of lead on activated carbons from olive stones J. Chem. Technol. Biotechnol., 36 (2), 47-52.

Rodríguez, MM., Pérez, J., Ramos, A., Martínez, M. (1988) Effect of extracts obtained from olive oil mill waste waters on Bacillus megaterium ATCC 33085. J. Appl. Bacteriol., 64, 219-226.

Ruíz, DR., García, Al., Moumen, A., Alcaide, EM. (2004). Ruminal fermentation and degradation patterns, protozoa population and urinary purine derivatives excretion in goats and wethers fed diets based on olive leaves. J Anim Sci., 82(10), 3006-3014.

Ryan, D., Antolovich, M., Prenzler, P., Robards, K., Lavee, S. (2002). Biotransformatios of phenolic compounds in Olea europaea L. Scientia Horticulturae, 92, 147-176.

Sánchez, J. (1998). Colorimetric Assay of Alditols in Complex Biological Samples. J Agric Food Chem., 46(1), 157-160.
Sánchez, S., Moya, AJ., Moya, M., Romero, I., Torrero, R., Bravo, V., San Miguel, MP. (2002). Aprovechamiento del residuo de poda de olivar. Ingeniería Química, 301, 194-202.

Sasazuka, T., Kameda, Y., Suzuki M., Hiwatashi, KH. (1995). Water-soluble oleanolic acid. Production, inhibition of insoluble glucan synthesis and antibacterial action Seito Gijutsu Kenkyukai Shi; 43:63-67.

Scheneder, L. (2003). Dietetic bread for diabetics Patent $N^{\circ}$ FR 2588159-A1 (08.10.1985).

Shtukatur, I. (2003). The technology of cracker production to improve the condition of sick people. Patent $\mathrm{N}^{\circ}$ WO 2004080203-A2 (11.03.2003).

Soler-Rivas, C., Espín, JC., Wichers, HJ. (2000). Oleuropein and related compounds. J. Sci. Food Agric., 80, 1013-1023.

Somova, LI., Shode, FO., Mipando, M. (2004). Cardiotonic and antidysrhythmic effects of oleanolic and ursolic acids, methyl maslinate and uvaol Phytomedicine, 11(2-3), 121-9.

Somova, LI., Shode, FO., Ramnanan, P., Nadar, A (2003). Antihypertensive, antiatherosclerotic and antioxidant activity of triterpenoids isolated from Olea europaea, subspecies africana leaves. $J$ Ethnopharmacol., 84(2-3), 299-305.

Soret, M. (1969). Antiviral activity of calcium elenolate on parainfluenza infection of hamsters. Antimicrob. Agents and Chemother., 9, 160-166.

Stone, WL., Leclair, I., Ponder, T., Bagss, G., Barrett-Reis, B. (2003) Infants discriminate between natural and synthetic vitamin E. Am.J.Clinical-Nutrition, 77, 899906.

Stoop, JMH., Williamson, JD., Pharr, DM. (1996) Mannitol metabolism: a method for coping with stress. Trends Plant Sci., 1,139-144.

Stueckler, F., (1998). Natural substance based agent. Patent No WO 9948386-A1 (24.03.1998).

Susnik-Rybarski, I., Mihelic, F., Durakovic, S. (1983). Antioxidant properties of substances isolated from olive leaves. Hrana i Ishrana, 24, (1-2), 11-15.

Tabera, J., Guinda, A., Ruiz-Rodríguez, A., Señoráns, FJ., Ibáñez, E., Albi, T., Reglero, G. (2004a). Countercurrent Supercritical Fluid Extraction and Fractionation of High Added-Value Compounds from a Hexane Extract of Olive Leaves. J. Agric. Food Chem., 52, 4774-4779.

Tabera, J., Ruiz, A., Señoráns, FJ., Ibáñez, E., Reglero, GJ., Albi, T., Lanzón, A., Pérez-Camino, MC., Guinda, A., Rada, M. (2004b). Procedimiento para obtener compuestos de alto valor añadido a partir de hoja de olivo Patent (29.03.2004).

Takeoka, G., Lan-Dao, L., Teranishi, R., Wong, R., Flessa, S., Harden, L., Edwards, R., (2000). Identification of three triterpenoids in almond hulls. J.Agric.Food Chem., 48(8), 3437-3439.

Tassou, CC., Nychas, GJ. (1994). Inhibition of Staphylococcus aureus by Olive Phenolics in Broth and in a Model Food System. J. Food Protection, 57, 120-124.

Tassou, CC., Nychas, GJ. (1995). Inhibition of Salmonella enteridis by Oleuropein in broth and in a model food system. Lett. Appl. Microb., 20, 120-124.

Tian, LT., Ma, L., Du, NS., Zhongguo-Zhong-Yao, ZZ. (2002). Survey of pharmacology of oleanolic acid. Chinese Materia Medica, 27(12), 884-6, 901.

Tranter, HS. (1993). The effect of the olive phenolic compound Oleuropein on growth and on enterotoxin B production by Stapylococcus aureus. J. Appl. Bact., 74, 253-259. 
Trovato, A., Forestieri, AM., lauk, L,, Barbera, R., Monforte, MT., Galati, EM. (1993). Hypoglycaemic activity of different extracts of Olea europaea $L$. in the rat. Plant Med Phyother., 26(4), 300-308.

Unterberg, AV., Kiening, KL., Hartl, R., Bardt, T., Sarrafzadeh, AS., Lanksch, WR. (1997). Multimodal monitoring in patients with head injury: evaluation of the effects of treatment on cerebral oxygenation. $J$. Trauma , 42, s32-s37.

Vázquez-Roncero, A., Janer, ML. (1969). Acidos triterpénicos del olivo. Grasas y Aceites , 20, 133-137.

Verhe, R., Papadopoulos, G., Boskou, D. (1992). Preparation of hydroxytyrosol. Bull. Liason Groupe Poliphenols, 15, 237-244.

Virtamo, J., Edwards, BK., Virtanen, M., Taylor, PR., Malila, N., Albanes, D., Huttunen, JK., Hartman, AM., Heinonen, OP. (2000). Effects of supplemental alphatocopherol and beta carotene on urinary tract cancer: incidence and mortality in a controlled trial (Finland). Cancer Causes Control, 11, 933-939.

Virtamo, J., Pietinen, P., Huttunen, JK., Coronen, P., Malila, N. (2003). Incidence of cancer and mortality following alpha-tocopherol and beta carotene supplementation: a post intervention follow-up. Jama, 290, 476-485.

Visioli, F., Bellosta, S., Galli, C. (1998). Oleuropein, the bitter principle of olives enhances nitric oxide production by mouse macrophages. Life Sciences, 62, 541-546

Visioli, F., Galli, C. (1994). Oleuropein protects low density lipoprotein from oxidation. Life Sci., 55, 1965-1971.

Visioli, F., Galli, C. (2002). Biological properties of olive oil phytochemicals. Critical Reviews. Food Science and Nutrition, 42, 209-221.

Visioli, F., Galli, C., Bornet, F., Mattei, A., Patelli, R, Galli, G., Caruso, D. (2000). Olive oil phenolics are dose- dependently absorbed in humans FEBS Lett. 468 (23), $159-160$.

Vlyssides, AG., Loizides, M., Karlis, PK. (2004). Integrated strategic approach for reusing olive oil extraction. J. Cleaner Production., 12, 603-611.

Wisselink, HW., Weusthuis, RA., Eggink, G., Hugenholtz, J., Grobben, GJ. (2002) Mannitol production by lactic bacteria: a review. Int. Dairy J., 12,151-161.

Yahiaoui, R., Guechi, A., Lukasova, E., Girre, L. (1994) Mutagenic and membranal effect of a phytotoxic molecule isolated from olive leaves parasitized by the fungus Cycloconium oleaginum Cast. Mycopathologia, 126(2), 121-129.

Yim, TK., Wu, WK., Pak, WF., Ko, KM. (2001). Hepatoprotective action of an oleanolic acid-enriched extract of Ligustrum lucidum fruits is mediated through an enhancement on hepatic glutathione regeneration capacity in mice. Phytother. Res., 15(7), 589-592

Yoshikawa, M., Matsuda, H., Harada, E., Mukarami, T., Wariishi, N., Murakami, N., Yamahara, J. (1994). Elatiside $\mathrm{E}$, a new hypoglycaemic principle from the root cortex of Aralia elata Seem.: structure related hypoglycemic activity of oleanólic acid glycosides. Chem. Pharm. Bull., 42(6), 1354-1356.

Zanichelli, D., Baker, TA., Clifford, MN., Adams, MR. (2005). Inhibition of Staphylococcus aureus by oleuropein is mediated by hydrogen peroxide. J. Food Protection. 68 (7), 1492-1496.

Zarzuelo, A., Duarte, J., Jiménez, J., Gonzalez, M., Utrilla, MP. (1991). Vasodilator effect of olive leaf. Planta Medica, 57(5), 417-419.

Recibido: Septiembre 2005 Aceptado: Noviembre 2005 